\title{
Land Rights At Last!
}

\section{Heidi Norman}

We're asking all students and all clubs, all unions and the workers to come out on July 14, [1972] to ask that land rights be recognised. Briefly land rights means: a claim that all Aboriginal reserves be immediately deeded in perpetuity to the Aboriginal people as a whole.

Kevin Gilbert - call to rally at the Canberra Tent Embassy on what was National Aborigines Day, (quoted in Tatz 1975)

That 'real' land rights means more than simply returning title to existing reserves. It involves the granting of title to substantial areas of land in NSW.

Resolution of the NSW [Aboriginal] Land Council, meeting $10^{\text {th }}$ October 1981, Tranby College, Glebe.

\begin{abstract}
This paper is a history of the little understood events that led to the passing of the groundbreaking Aboriginal land rights legislation by the NSW Parliament in March 1983. This paper sets out to ask why and how, after over 200 years of colonial land dealings, the Government came to recognise Aboriginal interests and rights to land and the sorts of strategies initiated by the NSW Aboriginal community to bring this moment about. Through interviews with key participants and close study of the archive, this paper traces the events that led to the Wran Government's 1978 announcement to investigate a range of issues including Aboriginal land rights, how the Inquiry was run, the recommendations it made and, finally, the bill that was drafted and made law. This study contributes to an understanding of the Government's response to Aboriginal social and political activism and therefore a new moment in history whereby we can understand a more just, though not uncontested, relationship between Aboriginal communities and the state.
\end{abstract}

The demands for 'land rights' have been persistent since invasion, yet they have varied over time in response to specific issues and in relation to the wider political context. For example, land demands have at times encompassed claims for equal citizenship and against the removal or apprenticeship of children, for small tracts for co-operative farming, or for decent housing with running water and sewerage and an oven. In different ways, over the colonial period, land justice was framed to meet economic, social, political, cultural and spiritual demands or needs (Goodall 1996, Maynard 2007). Land has therefore functioned as a central organising and defining dimension of Aboriginal culture and identity and since colonisation, has been subject to immense rupture - at times by design but in other instances through the wider imperatives of colonial capitalism. Goodall (1996) through close study of the archive demonstrates that land justice has been an enduring demand since colonisation, however differently framed over time. In later 
work Goodall $(2004,2009)$ further illustrates through two 'biographies': one of an 'extraordinary woman', the late Isabel Flick, and secondly of a major Sydney River, how relationships and attachments to land have similarly been a complex story of continuity and change where relationships and connections to land were forged anew continuous with traditional cultural practices and remade according to the particularities of the colonial economy and administration. However, Goodall and others (e.g. Maynard, 2007) are less focused on the inter-relations between the state, power and Aboriginal land justice demands, in part this is because these studies are prior to significant changes in the way the NSW Government dealt with Aboriginal people.

By the mid-1970s, a new moment in the long story of land rights activism emerged and crafted the political climate for the Wran Government's announcement of the Select Committee Inquiry and for key members to recall that it was a moment where 'land rights time had come' (Keane pers. comm. 2008). But it is first necessary to track back a decade earlier and identify some other developments that contributed to the movement from the mid-1970s. Specifically, the land rights movement in NSW was galvanized anew from 1965 in response to the newly- elected Askin Liberal Government's renewed efforts to achieve assimilation, central to which was the revocation of reserved Aboriginal lands.

The decisions followed recommendations of the NSW Government 'Joint Committee of the Legislative Council and Legislative Assembly Upon Aborigines Welfare’ on welfare related issues, particularly education and housing, and 'other proposals necessary to assist Aborigines attain an improved standard of living' (Joint Committee 1967, vol.5, p. 5). The Report (1967) of the Joint Committee was critical of the Aboriginal Welfare Board's delay in bringing about the assimilation of Aboriginal people and recommitted the Government to achieving this goal more effectively. Central to this was the recommendation that Aboriginal reserve lands should 'in due course...disappear' and the decision to cease any further building, infrastructure or even maintenance with the long term plan to gradually 'divest itself' of reserve lands. Aboriginal people's long-standing demands for land, including greater control over reserve lands, and compensation for dispossession, were not considerations in the Committee's recommendations. These decisions significantly impacted many families who continued to live on AWB 
administered stations and reserves: in 1965, the Aborigines Welfare Board administered 14 stations totalling 2484 residents (including Woodenbong, Tabulam, Cabbage Tree Island, Burnt Bridge, Purfleet, Roseby Park, Wreck Bay, Wallaga Lake, Boggabilla, Moree, Walgett, Brewarrina, Cowra and Murrin Bridge) and a further 4000 residents lived on about 40 reserves or communities across NSW (Select Committee 1980).

The passing of the Aborigines Act 1969 that repealed the long-standing Aborigines Protection Act 1909, further accelerated the revocations of what for Aboriginal people was considered 'Aboriginal land'. The new laws abolished the central governing body of Aboriginal Affairs, the Aborigines Welfare Board, and transferred reserve land to the State Lands Department. These developments represented a complex mix of both a desire on the part of the NSW Government to soften its welfare authoritarianism through devolution of 'Aboriginal welfare' to the relevant functional state departments at the behest of the newly appointed Commonwealth body, the Council for Aboriginal Affairs (herein 'the Council') and to lessen the financial burden the Board posed, but mostly the new laws were informed by the logic of assimilation as both inevitable and, at the level of Government policy, equal and just.

The Council from the outset advocated a model whereby the states would continue to be responsible for Aboriginal Affairs with Commonwealth grants from assistance and the devolution of Aboriginal related programs to functional departments. Rather than centralisation, they advocated devolution to the functional state based departments. Council member, Barrie Dexter explains in his unpublished manuscript, 'Pandora's Box', that devolution to the relevant department would allow for expertise to be drawn upon and would be better funded than the prevailing welfarist administrative regimes. The Council argued Departmental responsibility would ensure Aboriginal people were given a service equivalent to what the rest of society expected and were entitled to. The Council, as can be seen in Dexter's reflection of the period was both constrained by the existing conservative welfare regimes in the north and the Federal Government and by their own assumptions about the inevitability of assimilation (see Dexter, chapter 20:5 for an account of the Council's political strategy). Tim Rowse (2000) suggests that for the Council assumptions about the 'north-south divide' shadowed their ideas. But at the least the Council's reforms, which were apparently influential in NSW, were premised on ideas of 
'integration’ as indicated by the Minister at the Cairns gathering of relevant state and federal Aboriginal Affairs agencies in place of the policy enshrined in the joint statement by the Commonwealth and the states as amended in 1965. Prime Minister McMahon, announced the 'Cairns Statement' on the 23 April 1971:

I do not like attempts to embody complex policies in single words like assimilation and integration, capable as they are of varied interpretations and often acquiring irrational associations. We believe that Aboriginal Australians should be assisted as individuals and, if they wish, as groups to hold effective and respected places with one Australian society with equal access to the rights and opportunities it provides and accepting responsibilities towards it. At the same time they should be encouraged and assisted to preserve and develop their culture - their languages, tradition and arts - so that these can become living elements in the diverse culture of Australian society.

But there were some modifications along the way in response to Aboriginal land activism, particularly reserve lands. Goodall (1996) explains that Reserve lands were understood by Aboriginal people as recognition of traditional land ownership, compensation for dispossession and as a promise from the English Crown of inalienable security of tenure. The Government included Aboriginal representation on the Board and established a highly constrained land recovery mechanism through the Aboriginal Lands Trust (herein 'the Trust') in 1972.

By 1969, some 25,000 acres of 'old reserves' had been revoked by the State government (McGuigan 1984). In response to this threat, different regional groups became organized and went on to form larger coalitions. On the North Coast, as the reserves were threatened with revocation, Pastor Frank Roberts Junior, along with other groups supporting co-operative farming, along with north-western NSW people, formed a 'Coalition of Land and Rights Council’ (Goodall 1996, pp.299, 336-337). This Council held a conference in Sydney in 1970, forming the 'Land and Rights Council'. The 'Land and Rights Council' drew together north coast and north-western peoples who were experiencing similar threats to their land. From 1969, there were various local responses to the revocations and against the deliberate depletion and neglect of reserve houses: in 1972, some residents of the reserve at Mulli Mulli, in the state's north, participated in a rent strike to highlight the sub-standard housing and government neglect. At around the same time, activists originally from Moree and living in Sydney began researching and documenting the 'land needs' of the NSW Aboriginal community. 
The campaign for land rights recognition, in response to the revocation of reserves, gained considerable momentum in terms of profile and awareness in the wider community, and was a coherent and uniting platform for the NSW Aboriginal community. The trade union movement was particularly supportive in part because of the connections between members and the land rights movement. Other social movements aligned in support of land rights included feminists, students and Labor groups. T-shirts and badges demanding land rights animated the newlyminted Aboriginal flag. The Commonwealth Government, despite contrary advice from its key advisory group, the Council, actively supported mining applications and this sector's interests, against the objections and legal actions by Aboriginal people, such as by the Yirrkala people in what is referred to as the Gove Land Rights Case'. The 'land rights' response by Prime Minister McMahon, in January 1972, was received with contempt by Aboriginal people and sparked a much wider national land rights movement.

The land rights struggle in NSW, now long-standing, had endured the tyranny and authoritarian rule of the Aborigines Protection Board and later the Welfare Board. The dispossession of Aboriginal people from their land in NSW was a long process but also one that was within living memory and included the loss or eviction from one's home. In the period from 1940, with the formation of the Aborigines Welfare Board, the reserve lands were reduced from 15,834 acres to 6,274 acres by 1963 . In a period of no more than 23 years, more than half of the reserve land had been revoked (McGuigan 1984).

The experience of dispossession from land, while a feature of Aboriginal life along the east coast since colonisation, was again intensified in the second half of the twentieth century. At the same time, Aboriginal people in what became the Northern Territory were beginning to feel the full brunt of colonial dispossession, as Europeans and the Government sought to regulate access to land, particularly for mining. Whilst the manner of dispossession from land differed greatly from the east coast to the north of the country, the experiences came to share a united political platform, articulating similar and different land demands.

\footnotetext{
${ }^{1}$ The Yirrkala people’s Gove Land Rights Case refers to Milirrpum v. Nabalco Pty. Ltd. (1971) 17 FLR 141.
} 
This was most apparent in the response to the Commonwealth's limited land rights response. Following unsuccessful litigation by the Yirrkala people, Redfern based Kooris and Murris, travelled to Canberra and set up what became known as the 'Aboriginal Tent Embassy' protest. Amongst other things, the protest challenged the assumed assimilation of south-eastern Aboriginal people and powerfully highlighted the ambiguous status of Aboriginal people in our own land. Importantly, the land rights movement came together as a national campaign. The limited response of the conservative Coalition Government following the 1967 referendum, as well as the state sponsored police violence to break-up the embassy protest, entrenched hostilities between the Aboriginal community and the Government and cemented the national land rights movement (Dexter unpub. man. AIATSIS Library, MS 4167, Rowse 2000). In part, the embassy activism also influenced the new policy direction of the reforming ALP National Government, led by Gough Whitlam in late 1972 where more substantial innovation in Aboriginal Affairs developed, including an inquiry into land rights recognition in the Northern Territory and overall policy framework of self-determination. Significant funding was made available for NSW projects in the areas of land recovery, services, employment and training and housing. Funding for the purchase of houses in Redfern, for example, responded to critical housing needs and was part of a wider employment and training program but was also framed as land rights, particularly as land was central to the making of an urban community and self-determination.

\section{NSW Government response: the Aboriginal Lands Trust}

The NSW Askin liberal government, in response to land justice demands, enacted the Aboriginal Lands Trust in 1972. The amendments to the Aborigines Act (1969), to establish the Trust, had implications for reserve lands. It was initially thought that the Trust, with its nine-member representative body, would hold title to all remaining reserves on behalf of Aboriginal people. The amendments establishing the Trust not only raised enormous anxiety about the security of reserve land but it was widely considered an inadequate mechanism for land recovery: that it did not deliver real land rights recognition. Concerns about the legitimacy and capacity of the Trust were well founded: some 4,300 hectares of reserve lands, held by the Lands Department, were transferred to the Trust freehold and a mechanism established for communities to make application to self manage their land. Of the 250 claims lodged with the Trust only a few were processed and actioned in the earlier period of the Trust (Wilkie 1985, p.11). 
The perception of the ineffectiveness of the Trust came to be pivotal in the campaign for 'real' land rights recognition. The Trust - its activities and the legacy it inherited shaped the NSW land rights movement - was central to the politics and factions that emerged in this period and continued to impact on the land rights movement following the passing of the NSW Aboriginal Land Rights Act, 1983.

The Trust, in effect, assumed responsibility for the management of reserves and housing formerly undertaken by the Board. It was an incredibly flawed model: housing stock on reserves was already chronically depleted and inadequate servicing had prevailed well before the Government's decision to cease maintaining reserve housing, to the extent that by 1978 it was noted that eight communities were without electricity, affecting some 480 residents, four communities had no sewerage disposal and 18 were without sewerage or septic systems affecting 2500 residents (Select Committee 1980, p.46).

\section{A New Wave of Community Activism}

The actions of the Trust and the criticism of its limitations further galvanized support, clarifying the demands for land rights. At this time, key people emerged and significantly shaped the development of land rights. The formation of the Black Defence Group was critical at this point. The Black Defence group drew together an alliance of Aboriginal people, active in a number of areas, and union and other community activists. The group was originally convened to fund-raise for the roll-out of Aboriginal Medical Services [AMS] across the country. Under the guidance of Redfern AMS coordinator, Naomi Meyers, the group produced a newsletter and fund-raising kit. With the support of many non-Aboriginal people, Defence member, Marcia Langton, explained that she travelled pillion on a motor-bike to various philanthropic organisations, including Rotary and Lions, in search of financial support to run an AMS for 12 months, after which time they

hoped government funding would follow. Writing initially under the banner, 'Koori-binna', the newsletter communicated the group's fund-raising activities.

Kevin Cook and Marcia Langton explain that Black Defence Group activism was influenced by representation from South Coast elders, Jack Campbell and Ted 'Gaboo' Thomas, who 
encouraged them to focus their efforts on land rights. South Coast elders impressed upon the younger activists that the most important issue was land rights and so the defence group shifted their focus to achieving this objective. Kevin Cook recalls that:

They came up and talked to us about setting up a different Act. The Lands Trust was operating at that time and people weren't too happy....it was widely perceived that the Act was no good. It didn't allow Aboriginal people to do anything for themselves (Cook pers. comm.. 2008).

With this influence, the Black Defence Group went on to organise a state-wide land rights conference, in 1977, at which the NSW Aboriginal Land Council (NSW ALC) was formed. The Conference, timed to coincide with the annual Aboriginal Rugby League Knockout Carnival being hosted in Redfern, drew a large and diverse crowd. The NSW ALC formed as an independent non-statutory, non-government funded body with Kevin Cook as the first chairperson. Marcia Langton, at the first press conference of NSW ALC, outlined some of their plans: 'We have decided to pressure the ALP to embark on a land acquisition program' and for the NSW ALC to become a statutory body (Langton 1997). Kevin Gilbert argued that the trust had proved to be 'totally inadequate to administer the several thousand acres of Aboriginal land it held' and hoped the NSW ALC would replace the Trust.

The Defence affiliated activists and now with the organisation of the NSW ALC was instrumental in pressuring the Government to respond to Aboriginal demands and eventually focus on land rights. Their success in having a motion put at the ALP state conference in the same year endorsing Aboriginal land rights further propelled a formal Government response. By 1978 the NSW Australian Labor Party ‘Aborigines’ policy included extensive reference to land rights. The Chair of the Aboriginal Affairs Committee and Defence member, Bob Bellear, had successfully put the motion at the state conference, and this included:

All crown land now being used exclusively as Aboriginal reserves to be vested in, and administered by, statutory bodies elected by and comprised of Aborigines.

An investigation into the leasing and occupancy of land which until recently has been Aboriginal reserve land or part of reserves traditionally occupied by Aborigines. Where possible and desirable these areas shall be handed over to the statutory Aboriginal body, or bodies, for their utilisation.

The $[N S W A L P] \ldots$ : 
recognises that land forms the cultural, spiritual, economic and social basis of Aboriginal communities;

believes that the granting of Land Rights to Aborigines is a most crucial and significant long term aspect of any policy affecting Aborigines.

The six-page policy document went on to say that, after consultation, a fully funded Aboriginal Land Commission would be established for the purpose of hearing and granting land claims, assisting applications to the Federal Aboriginal Land Commission and managing land on a needs and interest basis. The policy further called for a halt to any mining leases where there is land claim interest and for the establishment of Regional Land Councils throughout the state to manage land claims and management (including access and traditional hunting and fishing rights).

The NSW ALC met regularly across the state, stepped up the demand for reserve lands with claims for Terry Hie Hie in north western NSW Orient Point near Nowra by the Roseby Park community and Wallaga Lake on the south coast (Goodall 1996, p. 11).

Elected members of the Trust continued to attempt to negotiate a strong position and felt that they had some continuing authority because they were 'representative'. For example, when it came to the Government's land rights consultation, the Trust saw their 'representative' role as having some authority and asserted their right to make a submission direct to the Premier as a 'separate viewpoint', drawing on the Trust's 'own special knowledge of the Aboriginal communities which it represents’ (Aboriginal Land Trust 1981). The Trust minutes reveal the growing antagonism. When it came to the Land Rights Conference held at Morpeth on the $26^{\text {th }}$ September 1981, the ALT members expressed concern 'because of the unrepresentative nature of such forums' (Aboriginal Land Trust, Minutes, 4-10 ${ }^{\text {th }}$ December, 1981, page 11). On the proposed land rights conference (to be held at Sydney University, February 1982) the Trust moved a motion that they be fully consulted in the coordination of the conference. They also expressed concern about the elected Chairperson of the NSWALC, Mr Kevin Cook, 'and the recognition claimed by [him].., a person who had never gone through any process of election by the community'. They also 'expressed concern' that 'Cook and the NSWALC were using the facilities of Tranby for purposes other than those for which funds had been donated' (Aboriginal Land Trust, Minutes, 29-30 ${ }^{\text {th }}$ June, 1982, page 17). The Minutes also indicate a naivety on the 
part of Trust members about the movement developing around them. They appeared to understand criticisms of the Trust as one of 'image'. For this they decided to embark on a PR campaign, such as through the production of videos and calendars. The political activism by the NSW ALC for more substantial land rights recognition created a significant split between those aligned with the Trust and the land rights movement that drew on alliances amongst the left and continued to advocate grass roots political activism and community control. These factors contributed to decisions of the Trust being widely perceived as 'self-serving' and in more disparaging terms as 'Uncle Tom's' and 'Jackey Jackeys' (Cook pers. comm. 2008, Langton pers. comm. 2008).

The formation of the NSW ALC and its effectiveness are generally attributed to the organising capacity of its Chair, Kevin Cook. He was able to draw support from a range of organisations, individuals and communities. His organising skills were honed through the trade union movement: a former dogman and rigger, he went on to work as an organiser with the Builders Labourers Federation (BLF), up until 1970. He grew up in an industrial, heavily unionised region, and his politics and ideas were in part shaped by the union movement. Cook's contacts with the BLF continued, and several members were part of the Defence group and had been involved in other activism with the Redfern Aboriginal community. NSW BLF President, Bob Pringle, for example, was active in anti-racism campaigns, particularly against the 1971 Springbok tour. The links between individuals that extended through key organisations and networks were highly significant in this period. Alf Clint, the founder of Tranby Aboriginal College (1957), whom Cook succeeded, drew extensive support from the Union movement including the wharfies, seamen, miners, teachers, builders and others. Political alliances, combined with the institutional support of Tranby, were critical in the early years of the land rights movement (and in following years).

Connections with the Union movement, particularly the BLF, with its extended political philosophy that linked the 'environment' and 'workers' rights' with wider social movements, enhanced the success of the land rights movement because this provided an extended political base from which to argue Aboriginal land and environmental rights. A vital network, established by Cook and others across the union movement, was the Trade Union Committee for Aboriginal 
Rights (TUCAR), allowing for wide and quick dissemination of news across the trade union movement. Cook says:

Rather than go to every union we had a core committee who would go back to the union movement and spread the word (Cook pers. comm.. 2008).

The NSW ALC drew on the institutional support of Tranby where Cook worked. They held meetings all over the state, with many western and south coast representatives attending regularly. Often meetings were held at Dubbo as this was most central, with delegates travelling by train from the north coast joining the bus at Tranby to attend meetings. This was a wide network of resourceful and dedicated individuals. While some communities were not able to make the meetings, they continued to organize at the local level.

\section{Government}

Election of the Wran labor government, in 1976, following the decade-long reign of the liberal government, created new opportunities for social change. The member for Woronora, Maurie Keane, explains his motivations:

When I went into Parliament [1973 and Government in 1976] it was my desire to do something that impacted upon the welfare of people. I had always had an affinity with Aboriginal people. I always felt it was unjust and unfair the way they were treated going way back... NSW had the highest number of people living in the worst possible conditions. It was accepted that that's the way it was. I felt strongly that we should do something about this. It was basically an idea and a desire that I had in my head and a matter of translating this into practicality (Keane 2008).

Keane recollected that he initially approached the then Premier, Neville Wran, with his general idea and desire to 'do something' for Aboriginal people. With the Premier’s support Keane took his idea to caucus and successfully convinced members that they should proceed to an Inquiry. With the support of the Premier and another key Minister, Frank Walker, Keane’s 'desire’ was in motion with the appointment of an all party 'Select Committee of the Legislative Committee Upon Aborigines’ convened by November 1978, with Keane himself as Chairperson.

The terms of reference were to inquire into:

The causes of socio-economic disadvantages of Aboriginal people, particularly in the areas of housing, health, education, employment, welfare and cultural issues; 
Effectiveness of commonwealth/state arrangements in Aboriginal Affairs;

Land rights for Aboriginal people in NSW.

It was South Coast elders who again exercised their influence and successfully persuaded the Select Committee to focus initially on land rights and further to expand the terms to include sacred and significant sites. The remaining terms of reference were held over for the Second Report (Select Committee 1981).

The work of the Committee revolutionized the NSW Government's approach to consultation with Aboriginal people. This was from the outset a clear goal of the Committee chair who explained:

I had looked at previous committees that inquired into Aboriginal matters, and there had been many, that those Committees composed of Parliamentarians rarely consulted the Aboriginal people in their deliberations. They seemed to concentrate on going to the councils in rural areas and suburban areas, meeting Aldermans, asking their opinion of Aboriginal situations but never asking the Aboriginal people and I was determined that I wouldn't have a Committee that went down that path, so the first thing I did was ask the Premier's Department for funds to employ Aboriginal people to assist the Committee.

With the support of an Aboriginal Task Force that included researchers and liaison officers, the Committee consulted widely, circulated a newsletter 'Koori-Murri: Liaison News and Views' that extensively documented and reported back to the community their work, and its hearings were made as accessible to the public as possible. Keane argued that the appointment of ‘Aboriginal Liaison Officers' was imperative ‘to assist mutual understanding and knowledge between the committee and the Aboriginal communities' and that 'achieving the full cooperation of the Aboriginal community should be the highest priority to the Committee' (Keane nd, p.4). The Task Force included Aboriginal researchers and former Defence members, Marcia Langton (who resigned in June 1979 to continue her studies at the ANU) and Kevin Gilbert, and coordinator, Pat O'Shane, (who was appointed head of the Ministry of Aboriginal Affairs at the conclusion of the Select Committee). When the author asked Keane how he came to recruit such distinguished people, he jubilantly replied, 'they just appeared'. Perhaps we can liken the land rights movement as a kind of (relatively) benign 'Trojan horse': the movement had so successfully approached and infiltrated the Parliament that the demands appeared organic and seamless. Where a movement that was shaped by its alliances, tension with the Trust, charisma 
of its leadership and by its long and enduring cultural continuity the movement had reached, as Keane recalls, a 'magical moment' where people appeared and things happened.

They actively sought to engage Aboriginal people in the process. For example, the Committee met at different places, including reserves, community halls and open-air gatherings. On one occasion, the Committee members visited a camp where they perched up on old car seats around a camp-fire where there was no running water, sewerage, or electricity. On another occasion, in a hall setting, the Committee was dramatically confronted by a naked Aboriginal man menacingly clutching several spears (Langton pers. comm. 2008). Confrontation was avoided with the deft intervention of one of the taskforce members, however these examples demonstrate that the Committee members genuinely engaged with Aboriginal people. In the interests of wide and genuine consultation they moved outside the confines of Parliament House and into very unfamiliar and uncontrolled environments.

The Committee encouraged direct representation from community members and informally consulted throughout the community. The committee invited by letter 886 individuals, 76 local government bodies, and 306 other organisations. 145 witnesses appeared before the Committee, submissions were received from 55 individuals, 5 local governments, and 57 other organizations (Select Committee 1980). They considered running radio advertisements to attract representation to the Committee. The draft scripts, that have a superhero quality about them, were as follows:

'We aborigines are a passive race...but not for long, something has to be done...and quickly.' 'White Australians just don't understand... all we want is a fair go.'

Yes someone is going to do something about any problems the Aborigines have. The Select Committee of the Legislative Assembly Upon Aborigines. If you have a recommendation or point of view... ${ }^{2}$

The Committee accepted representation and submission outside the standard format. For example, Guboo Thomas and Percy Mumbulla, Yuin tribal elders, submitted to the Committee a magnificent bound photographic essay of their Wallaga Lake and South Coast mountainous country and people, with a petition to halt all logging and other activities that impacted sacred sites and traditional areas.

\footnotetext{
${ }^{2}$ Memo from Pat O’Shane to M. Keane, 15 August 1979. The memo expresses concern about the plans to cancel the radio advertisements as they are too expensive.
} 
Many submissions to the Select Committee continued to reflect the pre-occupation with assimilation and reject the principles of land rights. These objections were most clearly expressed in submissions by councils where the regional National Party had strong support. The Council of the City of Dubbo opened their submission to the Select Committee with the emphatic assertion that:

The question of Land Rights does not exist in Dubbo. (Kelly in Select Committee 1980).

Gilgandra Shire Council argued that the 'existing depravations and disadvantage are due to the poor attitude of the Aborigines to education, employment, self-help and promotion' and that 'Aborigines should have the same rights as anyone else, except where it can be established that there is a spiritual or tribal affiliation in respect of a certain area' (Cameron in Select Committee 1980). Bourke Shire Council warned of ‘a big and unpleasant backlash’ should the Committee’s recommendations be implemented. They warned:

The Land Rights issue alone is frightening and could cause a major upheaval. People will simply not be forced from their land' (Randall in Select Committee 1982).

The Keane Report contained a range of far reaching recommendations, unanimously endorsed all-party committee, including the basis for land claims that included traditional rights as well as long association, compensation and needs. The Report made the significant point, by way of introduction, that articulated the violent and bloody history of dispossession that Aboriginal people experienced at the hands of white Australia and the rightful compensation that is due. This was understood in terms of justice and compensation for wrongs of the past. Aboriginal people’s land rights were understood in very broad terms as traditional relationship to country and as a relationship that had developed over time. The Report reflected an understanding of cultural continuity and change as inevitable consequences of colonisation (Select Committee 1980). In later discussion Keane reflected on the ‘unique situation' of having unanimous crossparty support. This he argued was 'because they could see and hear the sincerity and could see the deplorable conditions as far as health, housing and education’. (Select Committee 1980). Keane explains that the Committee members, 'after visiting Aboriginal communities they became convinced, they saw with their own eyes and heard the evidence from Aboriginal people’. (pers. comm. 2008). 
The Report proposed to repeal the Aborigines Act 1969 and replace it with an Aboriginal Land Rights Act and Aboriginal Land and Development Commission Act. The recommendations also included the establishment of Aboriginal community councils reporting to regional Aboriginal land councils. The proposed Aboriginal Land and Compensation Tribunal would hear and determine land claims and grievances and report to Parliament. The Aboriginal Land and Development Commission would function to support the regional land and community councils in land-purchasing advice and financing. Significantly, the Report recommended a funding model based on $7.5 \%$ of state land tax revenue, half of which was to be invested, with the remainder to support the operations of the three-tier council, including administration and enterprise development.

The First Report acknowledged three key historical points. Firstly, in 1788 'Aborigines were in possession of NSW'; secondly, that land 'was and is the material and economic base of Aboriginal society'; and, thirdly, that there is a 'desire to retain distinct Aboriginal community life'. The Committee understood the granting of lands rights as 'an act of elementary justice' and 'due compensation for wrongful dispossession'. The Committee outlined that all Aboriginal people, including urban, rural and reserve communities would be given the right to claim Crown, lease and freehold land on the basis of needs, compensation, and long association or traditional rights (Select Committee 1980, p.2). The report also recommended an Aboriginal Land and Compensation Tribunal in the event of disputes over land and the establishment of an Aboriginal Heritage Commission to protect and maintain sites. Keane's First Report lived up to community expectations and was very well received amongst the Aboriginal community.

The Second Report concluded that the causes of deprivations are 'poverty, discrimination and indifference' whereby 'the white citizens of this state have founded their present affluence on the seizure of land that belonged for 40,000 years to the Aborigines' and that 'In less than 200 years whilst waxing fat ourselves, we have reduced our unwilling benefactors to penury’ (Select Committee 1981, p.x). The Second Report recommended the adoption of self-determination as a fundamental starting point in the development of approaches and programs in the areas of housing, health, education, employment, welfare and culture and for the renegotiation of 
Commonwealth/State funding and programs. These recommendations were couched in the broader framework of rights to be self-determining 'in respect of their social, economic, political and cultural affairs' and 'heritage, customs, languages and institutions' (Select Committee 1981).

The Select Committee, its terms of reference and efforts towards genuine consultation, and the involvement of Aboriginal people in the process through the Task Force, amounted to a significant change in how the NSW government related and engaged Aboriginal people in government decision-making.

Support for the Select Committee's land rights recommendations was widespread. A loose coalition of supporters from union, church/religious and student groups lobbied to support the Select Committee's recommendations and generate public support through education and awareness. For example, they distributed a 'Land Rights Lobby Kit'.

However, there were substantial problems afoot. One was related to the divisions at the community level between Kevin Cook's NSW ALC and the various Regional Aboriginal Land Councils that formed further to agitate for land rights, in anticipation of the legislation and the Trust. The second was that the Government began to distance itself from the First Report's recommendations.

\section{The Aboriginal Land Rights Act, 1983: a limited response}

By August 1980, one press article quoted the Premier, Neville Wran, and Attorney-General, Frank Walker, saying 'financial constraints would limit the implementation of the Select Committee recommendations' (Wilkie 1985, p.35). Forestry, mining, tourism and pastoral industries also made known their opposition to the Select Committee's recommendations and were able to exercise their influence inside the Parliament through their relevant government departments and Minister to Cabinet and outside through university and professional associations. The Local Councils, as indicated earlier, were also not only highly organised as a network but they had access to Ministers, the press and resources and were united in their opposition to the First Report's recommendations, particularly land recovery provisions. In December 1982, a further article referred to the Attorney General's recommendation for a new 
proposal to Cabinet to limit claims to unalienated Crown Land and open market purchases (Milliken 1982).

The draft land rights legislation was a long time coming. Two years after the Select Committee's First Report on land rights, and one year after the Second, welfare-related Report, the Ministry for Aboriginal Affairs circulated 200 copies of the Green Paper draft legislation, just days before Christmas, in December 1982. It was officially published in February 1983, just seven weeks before it was debated in Parliament and without the last-minute Cabinet changes. The Green Paper was widely criticized. Initially this was over the absence of consultation during the period of the drafting of the legislation and the short time frame between circulation of the Green Paper and it going to Parliament. The further amendments made in Cabinet were committed to without any possibility or intention of consultation with Aboriginal people.

The Green Paper was in three parts:

Why land rights?

Explanatory notes to the draft Bill and, Draft Aboriginal Land Rights Act, 1983.

As set out in the First Report, the Green Paper adhered to the same key principles:

Land in the State of NSW was traditionally owned and occupied by Aborigines;

Land is of spiritual, social, cultural and economic importance to Aborigines;

It is fitting to acknowledge the importance which land has for Aborigines and the need of Aborigines for land; and

It is accepted that as a result of past government decisions the amount of land set aside for Aborigines has been progressively reduced without compensation (Aboriginal Land Rights Act 1983, S.1).

The legislation established a three-tier land council network of local, regional and state offices. The ALRA replaced the Aborigines Act 1969 and abolished the existing ALT and its ninemember council. The Green Paper outlined that membership of Local Aboriginal Land Councils (LALC's) was open to all Aboriginal people residing in the LALC boundaries, that they were 
entitled to claim Crown land not required 'for essential public purpose' or lawfully used or occupied, and to purchase land. Successfully claimed Crown land was restricted to leasing under certain conditions and could not be sold or developed.

The legislation was extremely disappointing for the Aboriginal community. It was widely argued that the consultation process was inadequate, that land recovery was severely constrained and the compensation fund inadequate. Unlike the extensive consultation that informed Keane's Select Committee, the Ministry for Aboriginal Affairs did not consult the community on the framework, but rather made available a small amount of money for communities to initiate their own discussion (Wilkie 1985, p.39). Despite the challenging release time and minimal circulation, the Green Paper was circulated, discussed and debated amongst the rapidly forming land council network. With assistance from legal officers from the Aboriginal Legal Service, community gatherings convened and scrutinized the draft legislation. Despite these limitations in time, resources, expertise, advice and organised support from Government, many communities did manage to gather and comment on the Green Paper. The highly organised Wiradjuri Land Council, for example, began holding meetings days after the Green Paper was circulated on Christmas Eve of 1982.

The NSW ALC state conference, in February 1983, with representation from all affiliated land councils, was very critical of the draft legislation and argued the Green Paper was not a 'land rights settlement' and, 'It does not compensate us for our loss or suffering' (Cook quoted in Wilkie 1985, p.iv). Bob Bellear, Chair of the State ALP Aboriginal Affairs Policy Committee and Uniting Church Board for Social Responsibility, said the Green Paper was out of step with the Select Committee proposals, 'lacked principles' and amounted to a 'betrayal'.

Some of the more specific criticisms of the Green Paper included the lack of clarity about specific rights especially traditional fishing and hunting rights, heritage protection, mineral rights, and the ability to recover land of cultural significance contained within National Parks and nature reserves under the National Parks and Wildlife Act 1974. The Minister for Aboriginal Affairs flagged the establishment of an Aboriginal Heritage Commission Bill 'for the protection and ownership of sacred and significant sites' although this was never pursued (NSW Legislative 
Assembly Hansard 1983, p.5090). Other concerns were that the Aboriginal Land Rights Act (ALRA) constituted land councils as non-statutory bodies governed under the Act, rather than as a company and subject to those rules and that the Act gave the Minister considerable power over the land councils through the appointment of administrators (Cook pers. comm.. 2008). There was further concern that the compensation provisions, 7.5\% of land tax revenue over 15 years, amounted to inadequate financial compensation for the loss of land, culture, and other deprivations in light of the constrained land recovery under the ALRA.

The Green Paper was perceived as a fundamental failing on the part of the Government to honour the promises made to Aboriginal people. At the Wiradjuri Land Council meeting 'everyone agreed that the land rights offer to the Aboriginal people of New South Wales in this Green Paper was a disgrace’ (Macdonald 2004, p.12). The Wiradjuri people’s meeting in January 1983 passed two motions condemning in strong terms the Green Paper. In writing to the Minister, Frank Walker, the Wiradjuri Land Council said:

...the Green Paper on Aboriginal Land Rights in New South Wales is totally unacceptable to the Wiradjuri Land Council and therefore is not to be tabled in the New South Wales Parliament. It is further moved that funds for local and regional meetings of Aboriginal people be allocated immediately to allow for proper consultation to occur. The results of such consultations are to form the basis for amended legislative proposals to be drawn up.

That the lands allocated in the proposed legislation, the compensation based on seven and one half per cent of the New South Wales Land Tax, the length of time such compensation is to be paid, and the restrictions on mining rights are totally inadequate and are not acceptable (Macdonald 2004, pp.12-13.).

Macdonald's (2004) intimate cultural study of this critical period for the Wiradjuri community provides an interesting counterpoint to the more political and historical analysis developed in this paper. Macdonald's study highlights the continued optimism, for example, she describes the hastily convened meetings as 'spirited' and 'filled with enthusiasm' where collections were taken at meetings to cover costs for correspondence and where the desire to 'do things for ourselves' and 'not rely on Government' prevailed (2004, p. 13). Macdonald observed that during this stage of the land rights negotiations, Wiradjuri Land Council got to know the Green Paper very well and assisted others in comprehending and analyzing the implications.

Despite the many positive developments at the local level, the passing of the legislation was a 
highly political process. The Government was concerned simply to get the Bill, however 'imperfect', across the line. The Liberal Party, in an 'unholy alliance', as Keane suggested, aligned with the discredited Trust and the ALS and moved to delay the passage of the Bill for a period of 6 months, ostensibly to allow for greater consultation (NSW Legislative Assembly Hansard 1983, p.5280). The Minister, Frank Walker, in meetings with Wiradjuri and in Parliamentary debate, acknowledged the Bill wasn't 'perfect' but that it was a 'start' that could be further amended and taken up with the Commonwealth Government (NSW Legislative Assembly Hansard 1983, p.5097). Debate amongst the Wiradjuri Land Council, and presumably others, came to be split over rejecting the flawed bill and seeing it as 'opening a door' to Parliament House, an argument made, among others, by Millie Butt in her capacity as liaison officer with the Ministry in a meeting of the Wiradjuri RALC. Labor members warned that if the Bill was to be delayed, opposition to land rights would develop further and put at risk any land rights legislation at all.

The consultation in the development of the draft Land Rights legislation came to be the key concern. While the Green Paper referred to 'exhaustive' consultation, this was highly contested by the Aboriginal people and even Members of Parliament who claimed they only received a copy a few days prior to Debate (NSW Legislative Assembly Hansard 1983, p.5280). However, consultation was never going to be possible or envisaged for some parts of the legislation subject to caucus deliberations. The Wiradjuri LC wrote to the Minister in March 1983 asking that the land rights bill be deferred until such time as consultation could occur and the response to community needs and priorities be taken into account (Macdonald 2004). Their concerns, as documented by Macdonald, were less about the principles of consultation but rather that the process would strengthen the legislation. They identified some specific problems and wanted the chance to remedy them. For example, they envisaged, perhaps rightly, that the three-tier network would create conflict because it centralized power with the state office, created a level of bureaucracy and administrative overload and there were insufficient funding provisions for administration. However, by this stage the legislation was very much part of a political process. When the author asked Maurie Keane about the consultation process and his views on the final legislation he was philosophical. He explained that politics, as the cliché goes, 'is the art of the possible'. He explained that some Committee reports never see the light of day, so the fact that 
the majority of the Committee's recommendations were endorsed, particularly the compensation package, was a significant victory. For Keane, this was the reality of political life (Keane pers. comm. 2009). Yet, for the thousands of Aboriginal people who gathered outside the Parliament, it was a moment of bitter disappointment as hopes had been raised so high and so much had been invested in the achievement of land rights.

Perhaps the biggest concern with the process related to another piece of legislation put before Parliament. The Crown Lands (Validations of Revocations) Act 1983 retrospectively validated the revocations of reserve lands that had been occurring since the late 1800s. The Act retrospectively validated or made legal the revocations of some 25,000 hectares of reserve land by the Government (McGuigan 1984).

The struggle for land rights as outlined in this paper related in part to the desire to stop the revocation of reserve lands and the assimilation agenda that this represented. The validating legislation amounted to tricky politics in the extreme. Not only did the legislation go against the key claims of the land rights movement, it was also apparently a complete surprise. The Ministry for Aboriginal Affairs was not responsible for its drafting, and at no stage, at the various forums that Ministers and staff attended, was the validating legislation mentioned to the Aboriginal community (Wilkie 1985, p.40). When the author asked Maurie Keane about the drafting he similarly declared no knowledge of the revocations legislation (Keane pers. comm. 2008). While the remaining reserve lands, estimated at about 4,300 hectares, were transferred directly to Local Aboriginal Land Councils, often this was with previously negotiated long-term lease arrangements continuing on title (Macdonald 2004, p.20).

As the two pieces of legislation were being debated, Aboriginal people gathered in the thousands. 'The mood', Macdonald says, 'was anger, frustration and betrayal', as numbers swelled outside well into the night and the Parliamentary debate continued in closed session (2004, p.6). There was a clear concern with the ALRA, particularly because of the limited consultation, but the validating legislation complicated and confused the situation. Macdonald suggests that it was difficult to mount 'two campaigns at once', even though they were so entwined (2004, p.20). The legislation in effect retrospectively legalised the revoking of 
Aboriginal lands, particularly as this was intensified in the second half of the twentieth century.

The ALRA recognised traditional meaning and association with place as well as adaptation and change through relationship to, for the most part, reserve lands, at least until 1983. The passing of land rights legislation - a Government mechanism to recognize and manage this association to land - while seen as a grave betrayal of Aboriginal people and of the Select Committee's recommendations, has also brought about, over 25 years of land council activity, the alignment of land rights with the means to economic and social independence. This paper has argued that Aboriginal land demands have been as dynamic as the colonial conditions have dictated: that is, Aboriginal land demands, however imbalanced, have necessarily been in dialogue with the state. We can see this in the expanding definition of land rights, in the NSW ALC's clarification on 10 October 1981, 'That 'real' land rights means more than simply returning title to existing reserves. It involves the granting of title to substantial areas of land in N.S.W.'.

From the mid 1970s, land demands were newly configured with a renewed level of intensity and clarity. This paper has identified the placement of key individuals within this moment - from the persistent encouragement of the Yuin elders, the organising ability of the Black Defence Group particularly as key members shaped ALP Aboriginal Affairs policy and formed the NSW ALC that further facilitated wider community organizing, the strategic alliances that were forged over a longer period but which came together in a reinvigorated way from the mid-1970s, and the wider social activism that left room for the complex articulation of land rights as a cultural, social, economic and political demand. This paper has also highlighted the perspective from 'inside' of Government, to understand how Government officials also understood the process that led to the achievement of land rights. At times the Aboriginal community, the 'outside' perspective, aligns with the 'inside' recollections. These accounts indicate how the Select Committee was fundamentally shaped by Aboriginal activism and strategic input to the Committee process whereby key members of the Parliament, supportive of Aboriginal social justice issues came to embrace the granting of land rights. 


\section{References}

Aboriginal Land Rights Act 1983, No. 42.

Aboriginal Lands Trust, Minutes and Annual Reports 1975-1982.

Background Paper: Aboriginal Land Rights Act (1983), NSW, accessed online

www.alc.org.au/news/alva/files/ALRA\%20Background\%20Paper.pdf, November 2005.

Cook, K. 2008, Interview with the author, August.

Crown Lands (Validations of Revocations) Act 1983.

Dexter, B., 'Pandora’s Box', Papers of Dexter Papers, Series 7, Item 11-15, held at the AIATSIS Library, MS 4167.

Goodall, H. 1996, Invasion to Embassy : land in Aboriginal politics in New South Wales, 1770 1972, Allen \& Unwin, Sydney.

Goodall, H., 2004, Isabel Flick: the many lives of an extraordinary Aboriginal woman, Allen \& Unwin, Sydney.

Goodall, H. and Cadzow, A. 2009, Rivers and Resilience: Aboriginal People on Sydney's Georges River, UNSW Press, Sydney.

Joint Committee of the Legislative Council and Legislative Assembly Upon Aborigines Welfare 1967, Report, Government Printers, Sydney.

Keane, M. nd, Background paper for Select Committee of Inquiry into Aboriginal Matters.

Keane, M. 2008, Interview with the author.

Keane, M. 2009, Interview with the author.

Langton, M., 1997, quoted in Aborigines seeking land rights change, Sydney Morning Herald, $3^{\text {rd }}$ October, page 8.

Langton, M. 2008, Interview with the author.

Macdonald, G, (2004) Two Steps Forward Three Steps Back: a Wiradjuri Land Rights Journey, Southwood Press, Marrickville.

Macdonald, G. 2004, Two Steps Forward Three Steps Back: a Wiradjuri Land Rights Journey, Southwood Press, Marrickville.

Maynard, J., (2007) Fight for Liberty and Freedom: the origins of Australian activism, Aboriginal Studies Press, Canberra.

McGuigan, A. 1984, Aboriginal Reserves In NSW: A Land Rights Research Aid, Occasional Paper no. 4, NSW Ministry of Aboriginal Affairs, Sydney.

Milliken, R. 1982 'Money, power battle embroils land rights', National Times.

New South Wales Aboriginal Land Council, Annual Reports 1985 - 2005.

NSW Parliament, Legislative Assembly, 1983, Hansard, Thursday 24 March, p.5090/

NSW Parliament, Legislative Assembly Select Committee Upon Aborigines, 1980, First Report from the Select Committee of the Legislative Assembly Upon Aborigines, Government Printers, Sydney.

NSW Parliament, Legislative Assembly Select Committee Upon Aborigines, 1981, Second Report from the Select Committee of the Legislative Assembly Upon Aborigines, Government Printers, Sydney. 
Rowse, T. 2000, Obliged to be difficult: Nugget Coombs’ Legacy in Indigenous Affairs, Cambridge University Press, Melbourne.

Stanner, W. E. H. 1968, After the dreaming, Crows Nest, N.S.W ABC Enterprises.

Tatz, C. 1975, Black viewpoints: the Aboriginal experience, Sydney, Australia and New Zealand Book Co.

Walker, F. 1983, Green Paper on Aboriginal Land Rights in New South Wales, issued by Mr Frank Walker Minister for Aboriginal Affairs, Government Printers, Sydney.

Wilkie, M, 1985, Aboriginal Land Rights in NSW, Chippendale NSW, Alternative Publishing Co-operative in association with Black Books. 